\title{
マリーナの係留保管料金設定に関する問題点 〜建設原価償還を前提にした場合〜
}

Ploblems of Pricing Marina Slip Rental Fees

$\sim$ In case of construction cost pay clear of $\sim$

渡会 英明*

Hideaki Watarai

\begin{abstract}
Pricing marina slip rental fees is a crucial financial consideration in marina planning. Unfortunately there are often serious problems in case of marina construction cost pay clear off. Because reasonable fees for average boat owners could not cover 100 percent of the construction cost. A new computer system that calculates standardized price units of rentable slip (such as Yen/foot) has already been developed and presented to the last symposium. In this stdury the problems of pricing marina slip rental fees have been made clear using the computer system and comparing with standard marina construction cost. This study therefore stands marina financial planner in good stead.

Keywords: marina slip rental fees, marina construction costs, computer analysis system, marina financial planning
\end{abstract}

1.はじめに

マリーナの経営は、採算上極めて難しい事業であることは各方面で指摘されてきた。残念ながら、ヨットや モーターボートに乗るということが、まだまた特定の富裕者層だけのレジャーであると判断されている我が国の 現状では、マリーナの建設原価の100\%利用者負担は、極めて当然のことと考えられている。このため、防波堤や 係留施設などのインフラ整備を含めたすべての建設原価を、利用者からの利用料金だけで償還しようとするた め、収支計算上で逆算された料金設定がとんでもなく高いものとなってしまい、事業実現が極めて困難となって いるマリーナが少なくない。

一方、著者は、昨年度の本シンポジウムにおいて、マリーナの適正な保管料金を経済理論を用いて演繹的に導 きだす手法を提案した。この手法は、あくまで地域のマリーナ需要に基づいて客観的に料金を算定するものであ り、「これだけ初期投資にかかるから、料金設定はこれ位に設定しょう」というようなナンセンンスな考え方に よるものではない。料金にはお扔ずから常識的な線があり、一般の利用者サイドに立った水準でなければ、需要 はあっても利用者がいない結果となる。つまり、利用者の集まるマリーナを計画しようと思えば、ある意味、考 え方の順序が逆の料金設定手法をとるのではなく、最初に常識的で適正な料金を設定し、この後、如何に建設原 価の償還を図るかを考えなければならない。

本研究においては、昨年度の手法によって算出された料金設定で、どこまでマリーナ事業の採算が取れるの か、細かな収益を積み重ねた上でも、「どこまでたったたら初期投資を負担できるのか」を数字で明確にし、これ らに関する問題点の具体化を図ることにした。

\section{2. 研究のながれ}

本研究を進めるにあたっては、まず、マリーナの施設整備事業主体と運営事業主体とは別との観点を置くこと にした。これは、設定された常識的な利用料金を、建設原価償還の有無にかかわらず恋動させないことを絶対的 な条件とし、運営事業主体が必ずしも初期の施設投資をすべて負担するものではなく、一部は地方公共団体など の別の事業主体か施設を単独で整備することを考えたためである。すなわち、運営事業主体は、施設整備事業主 体より低額もしくは無償で施設を借り受け、必要であれば、施設の管理運営を施設整備事業主体に代わって行な い、運営事業主体だけでも事業収支を成立させようという事業構図である。

しかしながら、著者の経験からすれば、仮に、施設整備事業主体が、外郭施設、倸留施設、ボートヤード、駐 車場などのインフラのほとんどを整備し、運営事業主体は、クラブハウス、浮栈橋などのごく一部の施設だけを 負担するという事業構図を考えたとしても、年間保管料は、最低でも20.000円/ftあたりに設定しなければ、採算 が取れないはずである。一般的なボートオーナーにとって無理のない値段設定であると思われる5,000 10.000円 /f程度の保管料の設定では、なんら施設投資の負担がなく、それら施設を無償で貸与されたとしても、単年度営 業収支は赤字になることは経験上から明らかである。

* 正会員 東急建設株式会社 技術本部 土木技術部 （150 東京都渋谷区渋谷1-15-21） 
そこで本研究においては、通常のプレジャーボート保管事業から得る営業利益で、運営事業主体が初期の施設 投資をどの程度負担できるかを算定してみることにした。具体的な方法としては、想定される標準的なマリーナ において、プレジャーボート保管事業の単年度営業利益をもとに単年度の借入金返済可能額を算定し、例えば開 業後12年などの適切な時期に、累積損益が黒字に転換できるような初期建設投資負担可能額（借入可能額）を想 定されるマリーナの規模別に推算した。また同時に参考のため、同様の規模におけるマリーナの必要標準建設総 事業費を算出し、これと、収支上から負担できる初期建設投資額を比較検討することにより、問題の具現化を図 ることにした。

\section{3. マリーナ営業収益の考え方}

\section{(1) 営業収入}

マリーナ事業というものは、プレジャーボートを保管するという事業を中心として、レストラン事業やその他 の関連事業などを組み合わせて複合化したものであるから、営業収益を考えるにあたっては、考えられるすべて の営業収入項目を検討しておかなくてはならない。しかし本研究においては、まず核となるプレジャーボート保 管事業の事業採算性に注目することとし、それ以外の、例えばレストラン事業などについては、独立した別の営 業収益のなかで考えることとする。

プレジャボート保管事業において、考えられる主な営業収入項目は以下のとおりである。

a) 保証金等収入 (保証金、入会金等)

b）艇保管料収入 (水面保管、陸置保管、艇庫、ラック等)

c）燃料売上収入（レギュラー・ハイオクガソリン、軽油）

d）上下架料収入（クレーン、スロープ、ウインチ等）

e）修理・部品売上収入 (エンジン・船体修理、部品販売等)

f）サービス施設等使用料収入 (水道、電気、ロッカー、シャワー等)

g) ボート・エンジン販売売上収入 (新・中古艇、エンジン)

h）保険等代理業務収入（ボート保険代理業務、船検代理業務等）

このほかにも、海技免許講習会やヨットスクールなどはシーズン中は大きな収入源となるものと考えられる が、ここでは、下線で示した項目か艇保管事業の基本収入であるとし、その他の収入項目に関しては、基本収入 に比べ付帯的であるとみなして検討外とした。

また、保管料金の設定にあたっては、ft単価の設定值を30ft陸置艇で10.000円から50.000円までの 5 段階に分

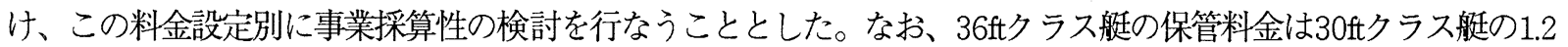
倍、50ftクラス艇は30ftクラス艇の1.4倍とし、水面保管艇の保管料金は陸置保管艇の1.2倍と設定している。

\section{(2) 営業支出}

マリーナ事業に対する営業文出には、プレジャーボート保管事業以外の仜带業務をどこまで行なうかによッて 異なってくる。ここでは、営業収入の考え方と同様に、プレジャーボート保管事業だけを対象とし、修理工場部 門などは外注委託することを前提とする。

考えられる主な支出項目は以下の通りである。

a）人件費（人件費、福利厚生）

b）物件費（水道費、電気光熱費、油脂燃料費、修繥費、備消品費）

c）経費（保険料、旅費交通費、通信運搬費、協議費·会費、交際費、宣伝費）

d) 土地賃借料等

e）水域占用料等（水面使用料、水面占有料、水域占用料）

ここでは、下線で示した項目を検討の範囲とするが、実際のマリーナ計画においては、実情に合わせて、その 他の項目についても営業支出に算入しなくてはならない。

上記項目の中では、人件費が最も大きな比率になると考えられるが、人員計画は、運営事業主体の種類・業務 内容などによって大幅に違い、一概に標準の人員配置基準と言えるものはない。本研究においては、人員組織 は、ハーバー部門、経理・事務部門などの必要最低限のものとし、舟艇販売などの営業部門、修理工場部門など は、運営事業主体の人員とせずに第三者に業務委託するものとする。したがって、修理工場部門の営業収入は マージン収入を考えるが、舟艇販売のマージン収入は、公共性の強いマリーナの性格を考えて考虑しないものと する。

また、土地賃借料、水域占用料等は営業支出の範用には含まれていない。これは、施設整備主体が整備した土 地、施設等は、運営事業主体に無償で貸与されることが条件であることを意味する。 


\section{4. マリーナ標準建設事業費の設定}

マリーナの艇保管規模は、あらゆる計画の参考となる様、最大500隻の保管規模まで検討を行なった。施設の整 備レベルについては意見が分れる所であるが、今回の検討では、全国のさまざまな計画に対応し得るようにマ リーナの施設の標準化をまず行ない、高級な施設でもないが、かといって簡易な施設でもない、言わば通常のレ ベルの施設を想定した。実際のマリーナ計画においては、その性格が千差万別であり、地域性、計画事業主体等 によって検討すべき内容や程度は異なる。従って、計画されるマリーナの状況に応じて、個々の条件にあった検 討を加えることが必要なのは言うまでもない。

マリーナの主な構成施設は次のとおりである。

a）外郭施設（防波堤、導流堤、防砂是、護岸等）

b）水域施設（航路、泊地等）

c）倸留施設 (岸壁、浮栈橋、倸留杭、倸留浮標等)

d）臨港交通施設（道路、橋梁等）

e）上下架施設（クレーン、フォークリフト等）

f）陸上保管施設（ボートヤード、艇庫等）

g）サービス施設（クラブハウス、修理工場、上下 水道施設、給油施設等)

h）安全施設（救護・救覲艇、無線装置等）

i）付帯施設（駐車場、緑地、教育訓練施設等）

i）利便施設（ショッピング、飲食、レクリエーシ ヨンの用に供する施設等)

\section{k）用地（上記施設の敷地）}

各マリーナは上記施設を必要に応じて組み合わせ て整備するものであるが、本研究において、マリー ナ運営事業主体が整備すべき施設は下線の範囲とし、 これら施設の建設コストのみ全体のマリーナ建設標 準建設事業費に集計した。つまり、これら以外の施 設に関しては、公共事業等によって整備されること

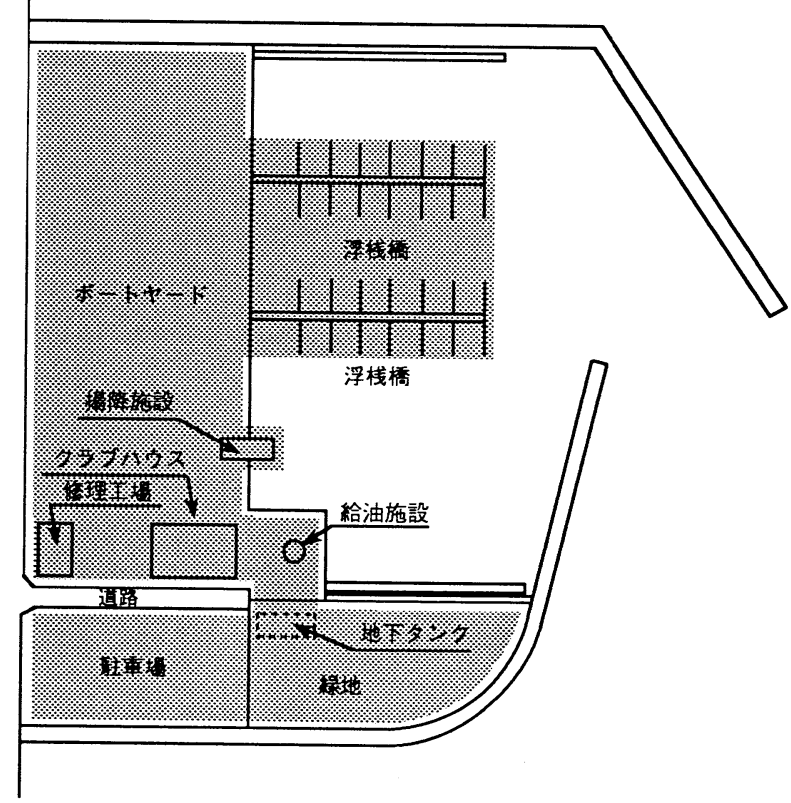

図－1 建設事業費算定の範囲 が大前提である。

\section{5.マリーナの事業採算性の評価}

本研究においては、ft単価の設定值を30ft陸置艇で10,000円から50,000円までの 5段階に分け、この段階毎に単 年度収益を借入金返济にあてるとして初期建設投資負扣可能額を算定し、必要な標準建設総事業費と比較した。

この結果によれば、概ね100隻以下の小規模マリーナにおいては50,000円/A以上、100隻以上250隻以下の中規模

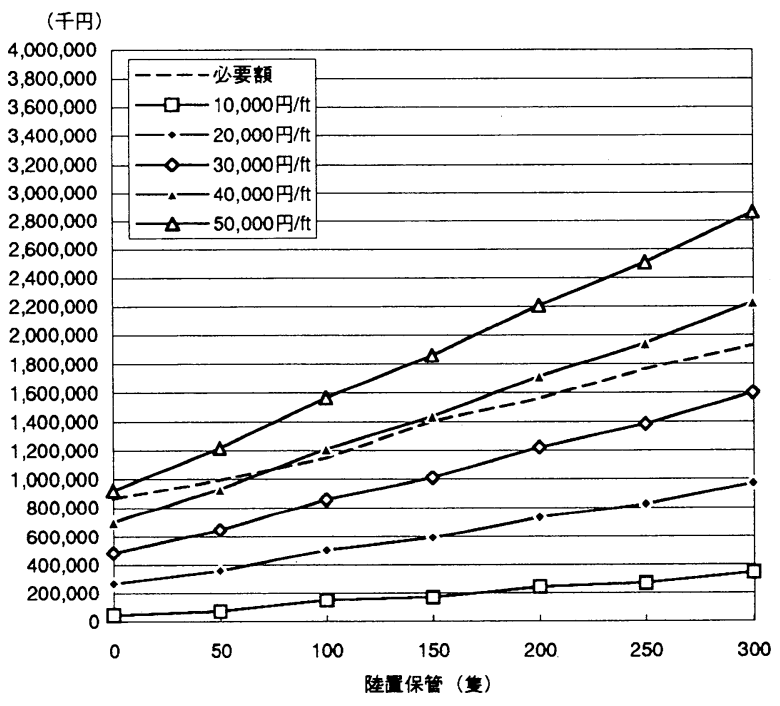

図-2 建設投資負担可能額（水面保管100隻）

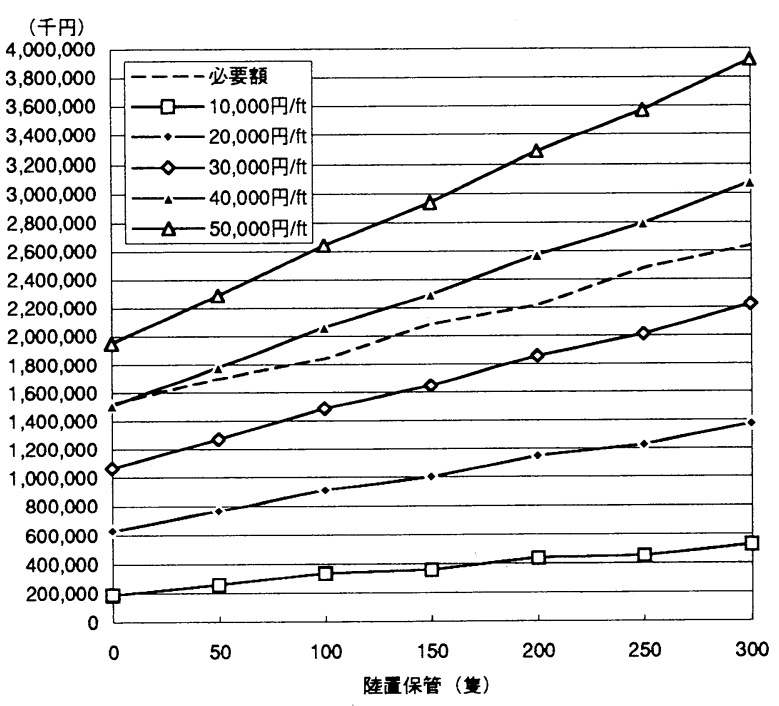

困-3 建設投資負担可能額（水面保管200隻） 
マリーナにおいては40.000円/ft以上の料金設定でないと事業収支黒字が見込めない。例えば、水面係留100隻、陸 置保管100隻の合計200隻規模の標準的マリーナにおいては、建設総事業費約12億円に対し、必要な保管料金は 40.000円/ftであり、これは、首都圈内等の極めて条件の良い場所においても事業を成立させるのは困難である。 さらに、防波堤や岸壁などのインフラ整備も受益者負担という考え方に基づくならば、100.000円/ftでも足りない ことが容易に予想できる。

また、運営事業主体の営業収益により負担可能な初期投資額は、保管料金が 10.000 円/ftで10 20\%、20.000円 /ftで35～50\%であり、一般のマリーナ利用者にとって常識的な利用料金である10.000～20.000円/ftでは、たとえ 種々の無利子・低利融資制度を活用したとしても、マリーナ運営事業主体にとって、必要な初期建設事業費の全 額を負担するのは到底不可能であることが明確になった。

\section{6. 事業採算性の実際例（大阪湾エリア）}

上記の問題を実際の地域にあてはめて考えるため、図一 4 に示すとおり、保管料金を比較的高く設定できると 思われる大阪湾岸の大阪府・兵庫県と、料金を低く設定せざるを得ないと思われる香川県・徳島県の 4 府県を取 り上げる。検討の手順は、まず各府県の市町村において適正なマリーナの保管料金の設定を行ない、この料金設 定をした場合のマリーナ建設投資負担可能額を算出して必要な建設総事業費と比較することにより、この問題の 地区別における具現化を図ることにした。

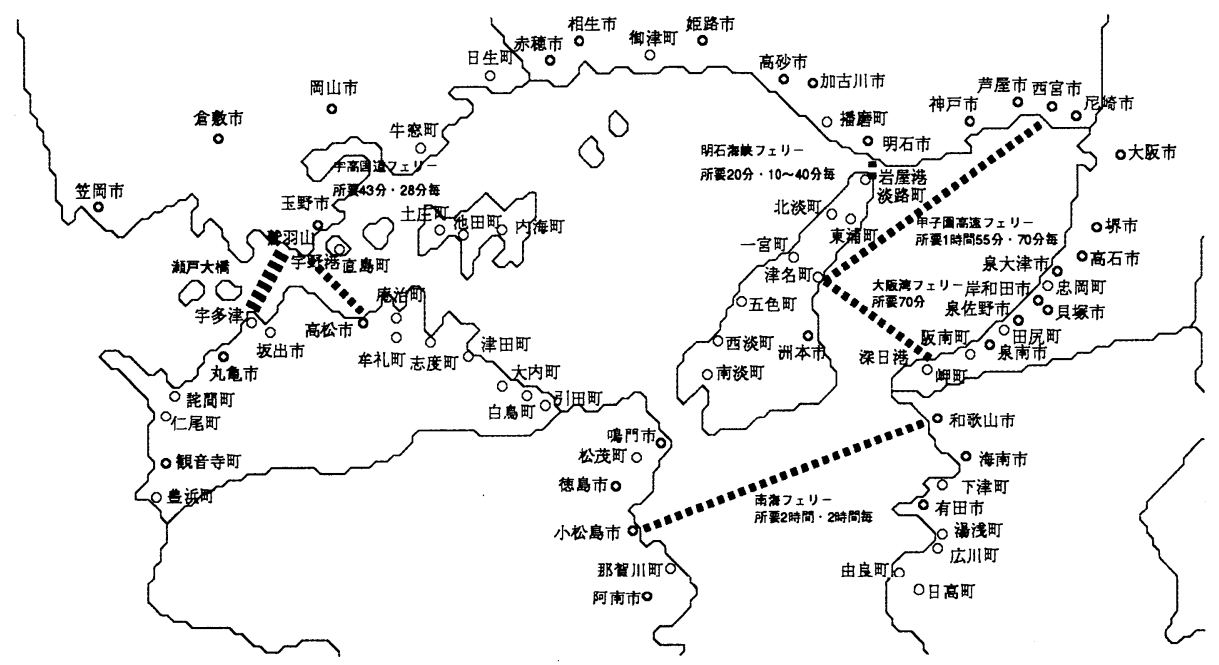

図一－大阪湾解析エリア図

\section{(1) 適正保管料金}

著者の昨年度までの研究により、全国任意の地点における、マリーナの適正保管料金の設定手法か確立され た。本手法は、任意の海岸線でのマリーナ需要を、「背後地での利用者発生ポテンシャル量」に比例し、「背後 地の利用者発生地からマリーナまでの到達抵抗」に反比例すると仮定したものであり、全国の既存マリーナの料 金設定をデータベース化して分析することにより、個々のマリーナ計画地での適正保管料金を演繹的に導きだす ことができる。なお、考え方の概念、計算方法などの詳細に関しては、後述の参考文献を参照されたい。

図一 5、6に、本手法により算出された各市町村における適正保管料金の結果を示す。これによると、本州側 地域においては概ね16.000 22,000円/ftであるのに対し、淡路島および小松島市以北の四国側地域においては 10.000 13.000円/ft、さらに徳島県南部では5.000 10.000円/ft以下と地域格差の大きいことがわかる。この結果 は、不確定要素の多いマリーナ適正保管料金を数值解析的に予測したものであるから、実際のマリーナ計画にお いてこの数值を採用する場合には、慎重でかつ弾力的な対応が必要となるが、著者の実地の調査によれば、これ らの数值は現地の実態をよく表わしており、概ね妥当な結果であると判断できる。

\section{（2）初期建設投資負担可能率}

図一 7〜10に、(1)で算出された適正保管料金を設定した場合の、初期建設投資負担可能率の計算結果をマリー ナの規模別に示す。

水面倸留100隻で陸置0３00隻規模のマリーナの場合、本州側で20～55\%、四国側で0～30\%であり、特に、徳 島県南部地域において陸置が200隻以下の場合には0\%となっている。同様に、水面倸留200隻で陸置0３00隻規 


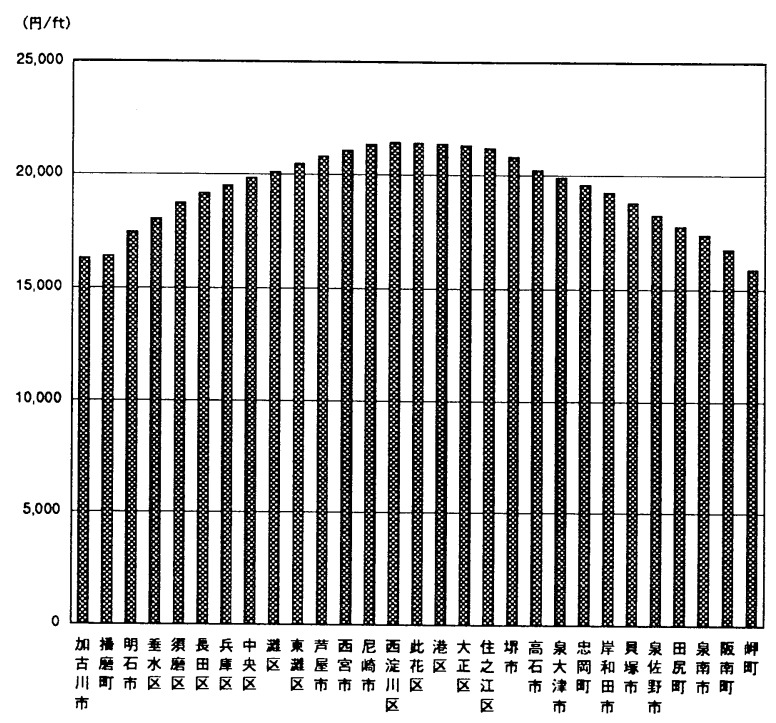

図-5 適正保管料金（本州側）

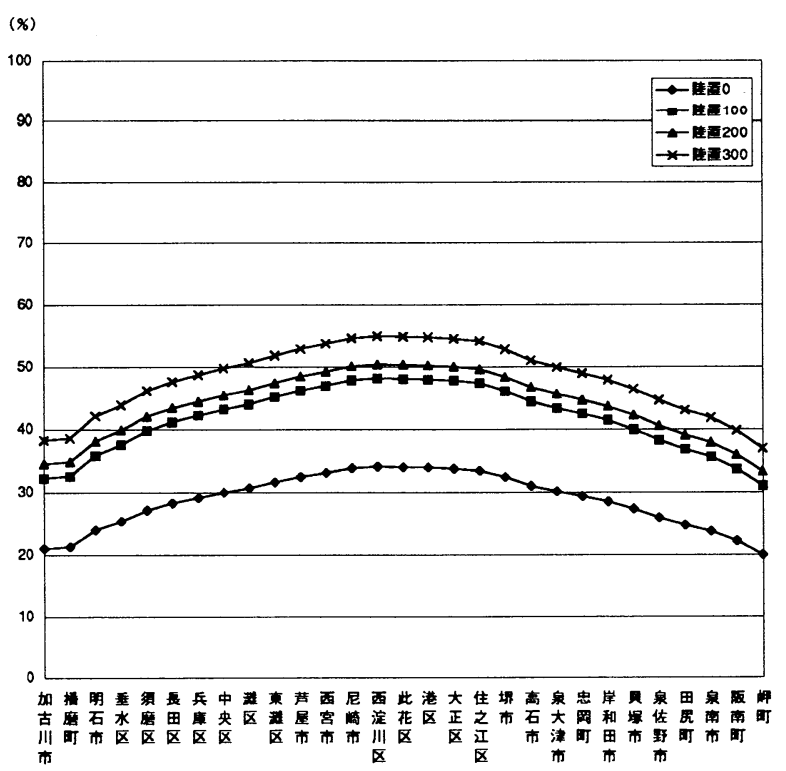

図-7 建設投資負担可能率（水面100隻·本州側）

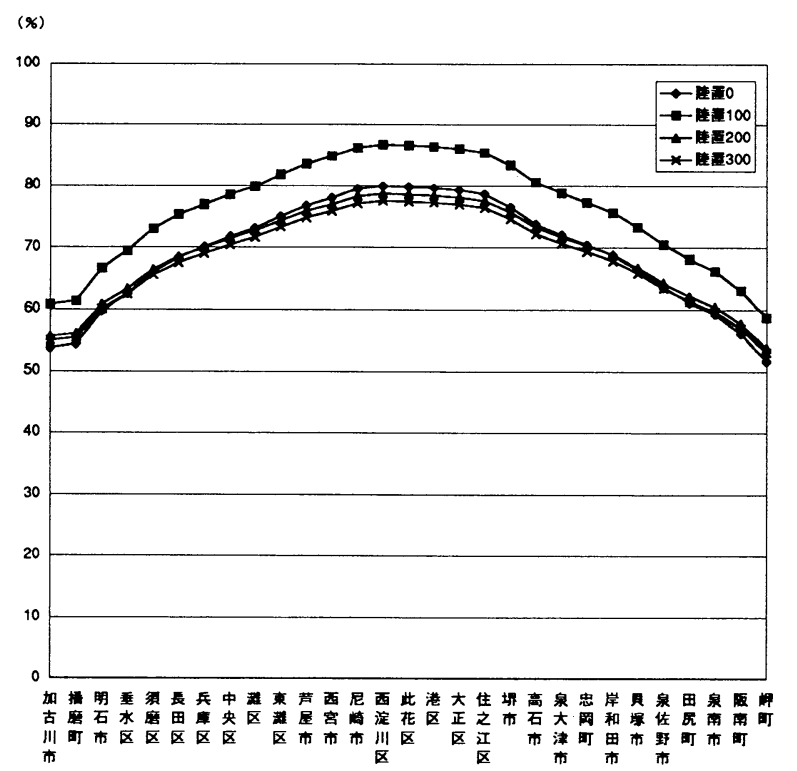

図－9 建設投資負担可能率（水面200隻・本州側）

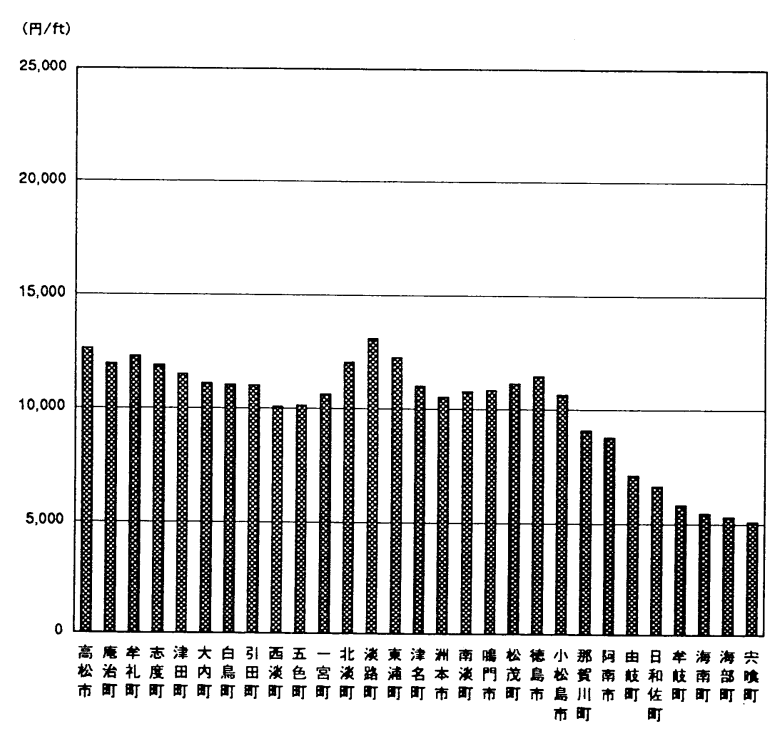

図-6 適正保管料金 (四国側)

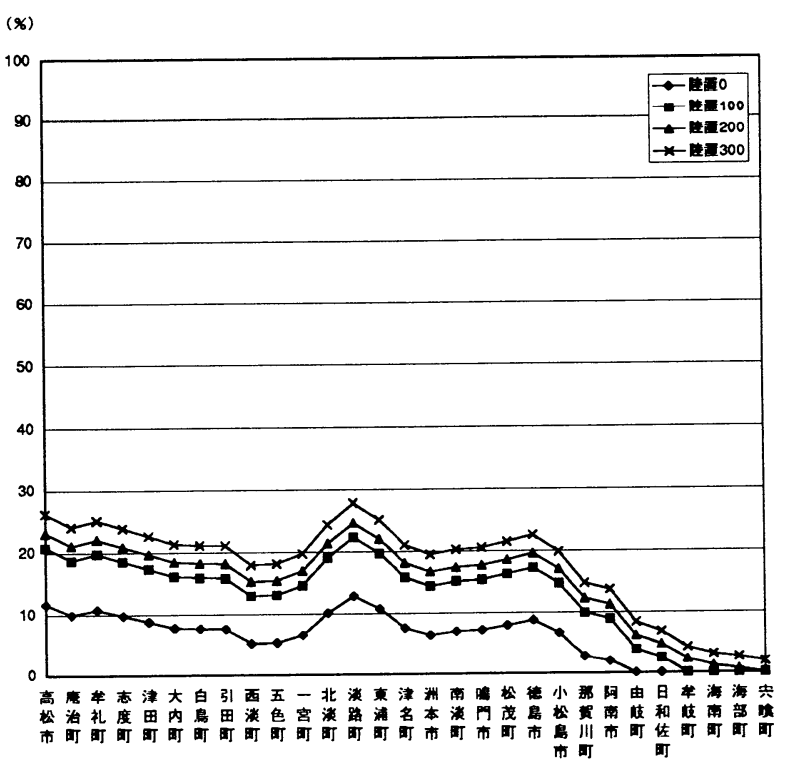

図-8 建設投資負担可能率（水面100隻 - 四国側）

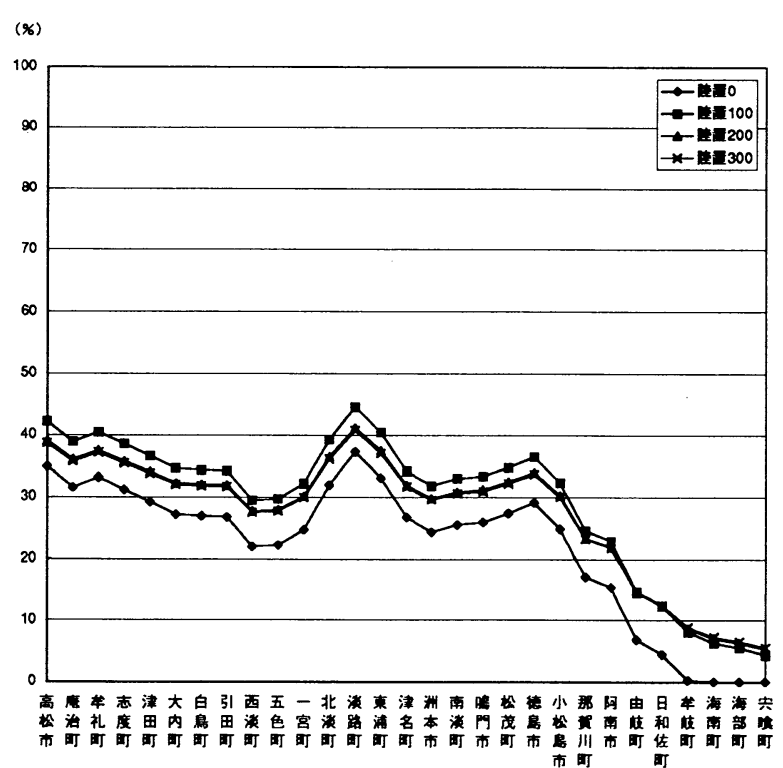

図-10 建設投資負担可能率（水面200隻・四国側） 
模のマリーナの場合、本州側で55～85\%、徳島市以北の四国側で 20～45\%、徳島県南部では0～20\%程度であ り、いずれの地域においても資金が大きく不足するという結果となった。マリーナの規模別に見れば、水面倸留 100隻の場合には、陸置0隻と100隻以上の間で差が大きく、これは、ある程度の規模以上のマリーナでなければ採 算性が特に悪いことを示している。

\section{7. 問題解決への提案}

前述のとおり、マリーナ事業においては、必ずしも運営事業主体が初期の施設投資をすべて負担するのではな く、政策的な判断から、公共による施設整備事業を導入しなければ事業が成り立たないということを示した。つ まり、マリーナ施設の整備事業と、その運営事業とは別との観点を置き、運営事業の収益の内容によっては、運 営事業主体とは異なる別の事業体（地方公共団体など）によって施設整備が行なわれ、その施設整備事業主体が 運営事業主体に施設の管理運営委託を行なうという事業構図を考えざるを得ない。施設整備事業主体といって も、これは、一般的には地方公共団体のことを指すわけであるから、公共が施設を整備し、民間は運営するだけ とういう事業構図でなければ基本的には事業が成り立たないということである。

しか、、一般的に言って、マリーナを一から作ろうとすれば、市町村の年間予算のかなりの部分を占める事業 費となることも珍しくなく、自治体自前の費用調達は困難となる。そこで、その資金の大半を民間企業に頼るわ けであるが、みすみす「採算割れ」するとわかってて対応してくれる企業がそうそうあるわけではなく、民間企 業としては、それ相応の施設整備を自治体側に行なってもらい、初期負担をかなり軽減した上での進出でなけれ ば事業に参画できないだうう。

やはり抜本的には、地方自治体、民間企業でマリーナの建設費用を賄えない以上は、外郭施設、護岸などのイ ンフラ整備に加え、クラブ八ウス、ボートヤード、浮栈橋、プレジャーボート揚降施設などの建設事業に関して も国庫補助事業で賄うしかなく、特に地方部の小規模マリーナにおいては補助率をかなり高めに設定せざるを得 ない。さもなければ、相当に余力のある地方自治体が単独でマリーナの基盤整備のすべてを行なうしかなく、低 利 ·無利子の公的融資制度や税優遇処置などの消極的・小手先的解決策では、なんら根本的解決にならないこと は明らかである。

\section{8.おわりに}

以上、マリーナの事業採算性について、建設原価償還を前提とした場合の問題点について論じた。やはり、マ リーナ事業とは儲かるものではないという認識を、公共、民間ともに持つ必要がある。しかし、マリーナ建設に 対する要求は大きく、都市部においては、プレジャーボートが港湾や河川に不法倸留され大きな社会問題となっ ている。これらの問題に対処するため、また、健全な海洋性レクリエーションの発展に寄与するため、官民とも に積極的にマリーナ建設を推進していかなくてはならない。それらの計画を進める上で、おそらく最終的には、 このマリーナの採算性が問題となるであろうし、それには非常に厄介な問題が含まれているのも事実である。

低料金と健全経営の二律背反というべき谷間の中で、相反する二つのことを成り立たせていくためには、建設 コストの大幅な削減を図るとともに、施設の整備と運営は別々に考え、施設整備は公共事業の一環で行なっても うらうのか唯一の解決策である。もともと公共性が高く、投資額も膨大なマリーナという事業を、一民間会社や 一地方自治体が単独で建設し運営するのにはおのずと無理があり、これは、行政側が、百年先をも見据えて取り 組むべき事業のはずである。

今後は、この「公共が施設を整備し民間が運営する」という考えを大前提に、運営事業主体は、より一層の経 営の合理化や多角化を図ることにより収支改善に努め、同時に、行政側も、財政・金融・税制面での積極的な支 援策を打ち出していかなければならない。そして、今は収支的に困難なマリーナ事業を少しでも改善し、日本全 国に数多くの健全なマリーナが実現できるよう関係者は邁進したいものである。

最後に、本研究を進めるに当たっては、多くの方々に御指導・御協力をいただいた。また、本研究のうち、 「マリーナ営業収益の考え方」および「マリーナ標準建設事業費の設定」については、平成 5 年度社団法人フ イッシャリーナ協会経営システム研究会で行なわれた研究をべースとしており、フィッシャリーナ協会および研 究に参加された関係者の方々よりさまざまな有益な御示唆をいたたいた。ここに記して深甚の意を表する。

\section{参考文献}

1）渡会英明（1994）：マリーナの倸留保管料金の設定手法に関する研究、海洋開発論文集（第10巻）

2）渡会英明（1995）：マリーナの立地需要予測モデルの研究、土木計画学研究・講演集（No.17）

3）社団法人フィッシャリーナ協会（1995）：平成5年度社団法人フィッシャリーナ協会研究会研究報告書 